\title{
Heat Shock Followed by Priming Increases the Quality of Agropyron elongatum Seeds under Accelerated Ageing
}

\author{
Malihe AKBARPOUR BAHREH*, Farzad SHARIF ZADEH, Alireza ABBASI \\ Department of Agronomy and Plant Breeding, Faculty of Agricultural Science and Engineering, College of Agriculture and Natural Resources, University \\ of Tehran, Karaj4111,Iran; ma_akbarpoor20@ut.ac.ir ("correspondingauthor)
}

\begin{abstract}
The present study was carried out to examine the possibilities of obtaining primed seeds that maintain high germination quality and the same longevity as the untreated seeds. For Tall wheatgrass tested, we found that the desired longevity could be obtained by keeping the seeds under heat shock for a period of several hours, after a priming treatment. Decreasing germination and seedling vigour in BAP 25 and $50 \mathrm{ppm}$, for 24 priming, did not happen again due to such a treatment. In addition, following priming, heat shock affects the initial quality of primed seeds in some treatments. Optimal temperature was strongly duration dependent. The method was applied to obtain primed seeds without the loss of storability, which is similar to those procedures used to induce desiccation tolerance in germinated seeds and acquire thermo tolerance in plant vegetative tissues.
\end{abstract}

Keywords: benzylaminopurine, heat tolerance, germination, longevity, seedling vigour, storability

\section{Introduction}

Over the past two decades, seed priming is used extensively in order to increase speed and uniformity of germination in the field, for a better establishment of seedlings and a faster passage to environmental unfavorable conditions during germination and emergence, etc. It is used in many important crops, such as wheat (Triticum aestivum), maize (Zea mays), pepper (Capsicum annuum), soybean (Glycine max), both for optimal and unfavorable environmental conditions (Iqbal and Ashraf, 2007; Farooq et al., 2008; Korkmaz and Korkmaz, 2009; Zhang et al., 2012). Despite the fact that priming has a large number of positive effects, when combined with subsequent desiccation, the effect of priming is not necessarily positive. In some situations, the benefit to germination is lost or partly retained on desiccation, or rapidly lost during storage (Bulter et al., 2009). Bruggink et al. (1999) advanced the hypothesis of longevity induction to primed seeds. Assuming that the mechanisms conferring longevity and desiccation tolerance are related to each other, treatments that induce desiccation tolerance should also have a positive effect on longevity. They used different treatments, including heat shock (Bruggink et al., 1999). Heat shock is often defined as the rise in temperature beyond a threshold level, for a specific duration. In general, a transient elevation in temperature, usually $10-15{ }^{\circ} \mathrm{C}$ above ambient temperature, can be considered as heat shock (Wahid et al., 2007). Seed aging is characterized by a sigmoidal relationship between viability and time (Walters et al.,
2010). Accelerated ageing (AA) has been recognized as a good predictor of seed' storability (McDonald, 1999). After aging period, high vigour seeds are expected to still show high germination, whereas low vigour seeds are expected to show a considerable decrease in germination (Kruse, 1999; ISTA, 2010). We have described heat shock treatments that induce desiccation tolerance in primed seeds. In fact, the aims of the present study were: (1) to characterize the sensitivity of primed seeds with different substance, to ageing conditions, (2) to investigate whether heat shock followed by priming induces seed longevity, (3) to determine whether heat shock followed by priming can be involved in the reinforcement of priming effects. Over the past two decades, seed priming is used extensively in order to increase speed and uniformity of germination in the field, for a better establishment of seedlings and a faster passage to environmental unfavorable conditions during germination and emergence, etc. It is used in many important crops, such as wheat (Triticum aestivum), maize (Zea mays), pepper (Capsicum annuum), soybean (Glycine max), both for optimal and unfavourable environmental conditions (Iqbal and Ashraf, 2007; Farooq et al., 2008; Korkmaz and Korkmaz, 2009; Zhang et al., 2012). Despite the fact that priming has a large number of positive effects, when combined with subsequent desiccation, the effect of priming is not necessarily positive. In some situations, the benefit to germination is lost or partly retained on desiccation, or rapidly lost during storage (Bulter et al., 2009). Bruggink et al. (1999) advanced the hypothesis of longevity induction to primed seeds. Assuming that the mechanisms conferring longevity and desiccation tolerance are related to each other, treatments that induce desiccation 
tolerance should also have a positive effect on longevity. They used different treatments, including heat shock (Bruggink et al., 1999). Heat shock is often defined as the rise in temperature beyond a threshold level, for a specific duration. In general, a transient elevation in temperature, usually $10-15{ }^{\circ} \mathrm{C}$ above ambient temperature, can be considered as heat shock (Wahid et al., 2007). Seed aging is characterized by a sigmoidal relationship between viability and time (Walters et al., 2010). Accelerated ageing (AA) has been recognized as a good predictor of seed' storability (McDonald, 1999). After aging period, high vigor seeds are expected to still show high germination, whereas low vigor seeds are expected to show a considerable decrease in germination (Kruse, 1999; ISTA, 2010). We have described heat shock treatments that induce desiccation tolerance in primed seeds. In fact, the aims of the present study were: (1) to characterize the sensitivity of primed seeds with different substance, to ageing conditions, (2) to investigate whether heat shock followed by priming induces seed longevity, (3) to determine whether heat shock followed by priming can be involved in the reinforcement of priming effects.

\section{Materials and methods \\ Plant material}

Tall wheatgrass (Agropyron elangatum) seeds used in this study were prepared from Bahar Researching Station of Hamedan, Iran $\left(34^{\circ} 48^{\prime} \mathrm{N}-48^{\circ} 31^{\prime} \mathrm{E}\right.$; AAP $\left.315 \mathrm{~mm}\right)$ and were kept at $3{ }^{\circ} \mathrm{C}$ until the beginning of the experiment. Seed moisture was measured before testing, by the oven method $\left(130{ }^{\circ} \mathrm{C}\right.$ for $1 \mathrm{~h}$ ) (ISTA, 1996), which was equivalent to $7.8 \%$. In addition, a germination test was carried out to assess the seeds' initial viability at $25^{\circ} \mathrm{C}$, which showed $98 \%$ germination rate, with normal seedlings.

\section{Priming treatments}

Seeds were treated with benzylaminopurine (BAP) solutions. BAP concentrations were 25 and $50 \mathrm{ppm}$. Hormone concentrations of appropriate were prepared. The seed subsamples were randomly selected and were placed in Petri dishes of $15 \mathrm{~cm}$ diameter, containing the above mentioned medium. Solution volume in each Petri plate was determined based on the grounds that the seeds should not be completely submerged in the solution, i.e. on one side they are almost in contact with air. Seeds were soaked in these solutions for 24 and $36 \mathrm{~h}$ at $10{ }^{\circ} \mathrm{C}$. After priming, seeds were washed several times with sterile distilled water, and then seeds' surface moisture was removed with blotting paper.

\section{Accelerated ageing test}

At the end of imbibition, part of the primed seeds were placed at the same temperature that were primed, in order to reduce the moisture content and reach the level of unprimed seeds, so that to be ready to perform accelerated aging (AA) test. Three AA regimes were performed, by suspending the primed and control seeds over $40 \mathrm{ml}$ of deionized water, on a wire mesh tray, in a closed plastic box $(11 \times 11 \times 4 \mathrm{~cm})$. The boxes were then placed in the incubator at a temperature of $41{ }^{\circ} \mathrm{C}$ for 0,3 and 6 day periods (Delouche and Baskin, 1973; ISTA, 2010). Relative humidity in the boxes was 90-95\%.

\section{Heat shock after-priming test}

The rest of the primed seeds were desiccated by means of exposing them to ambient temperature. This led to $10 \%$ decrease in moisture content (MC) (Bruggink et al., 1999). Afterwards, seeds of each treatment were separately foil wrapped, in order to avoid reduction of seeds' moisture. Next, seeds were stored at temperatures of 30 and $40^{\circ} \mathrm{C}$ for periods of one, two, three and four hours, after which they were transferred to $30{ }^{\circ} \mathrm{C}$, until the moisture content of the seeds reached the initial moisture level, before priming (Bruggink $e t$ al., 1999).

\section{Germination Assays}

Samples of 150 seeds (three replicates of 50 seeds) for each treatment were surface sterilized with $2 \%$ sodium hypochlorite for two minutes, to avoid fungus attack, and subsequently washed with sterile distilled water, before being used in the germination experiments. Seeds' surface moisture was removed with blotting paper and the seeds were placed in Petri dishes ( $90 \mathrm{~mm}$ diameter) with two moistened filter papers. Subsequently, Petri dishes were sealed in a plastic bag, to prevent evaporation, and were placed in the darkness for 21 days, at a temperature of $25^{\circ} \mathrm{C}( \pm 1)$ (ISTA, 1996), for evaluating germination behavior. Germinated seeds were counted daily. A seed was scored as germinated if its radical had $2 \mathrm{~mm}$. The rate of germination was estimated using Timson index (GI) as follows: $\mathrm{GI}=\Sigma(\mathrm{Gt} / \mathrm{t})$, where $\mathrm{Gt}$ is the number of germinated seeds per day t (Patade et al., 2009; Zhang et al., 2012). The higher value of Timson's index indicates a more rapid rate of germination. The seedling vigour index (SVI) was calculated as SVI= Seedling length $\times$ Normal germination percentage (Abdul-Baki and Anderson, 1973).

\section{Statistical Analysis}

Analysis of variance (ANOVA; $\mathrm{P}<0.05)$ for comparing treatment effects in both factorial experiments was conducted, in a completely randomized design (CRD), with 3 replications. Arcsine data transformation was performed on percentage data before the analysis of variance, to ensure homogeneity of variance (non-transformed data appear in all tables and figures). All data were analyzed via SAS v.9.1. If the ANOVA showed significant effects, Duncan's multiple range test $(\mathrm{P}<0.05)$ was used to determine differences among treatments.

\section{Results and Discussion \\ Accelerated Ageing after Priming}

Accelerated ageing resulted in a statistically significant reduction of the germination percentage (GP) of the observed primed and non-primed seeds $(\mathrm{P}<0.0001)$. The interaction between priming and AA was significant for all traits (Germination Percentage: F-Value $=7.44, \mathrm{P}<0.0001$; Normal Seedling Percentage: F-Value $=3.9, \mathrm{P}=0.0029$; Seedling Vigour Index: F-Value $=6.12, \mathrm{P}=0.0001$ and Germination Index F-Value $=22.1, \mathrm{P}<0.0001)$.

Accelerated ageing negatively affected all traits. The GP was significantly affected by AA in primed and unprimed seeds (Fig. 1). Under free ageing, no significant differences were observed between primed and unprimed seeds (Fig. 1). 
258

After three days of ageing, the highest and lowest GP allotted to BAP $50 \mathrm{ppm}$ for $24 \mathrm{~h}(\mathrm{GP}=92 \%)$ and unprimed $(\mathrm{GP}=63 \%)$ respectively (Fig. 1[A]). In six days of AA, GP in both primed and unprimed seeds was significantly declined. However, BAP $25 \mathrm{ppm}$ for $24 \mathrm{~h}$ with $55 \%$ germination was the best result. The lowest GP was devoted to BAP 25 and $50 \mathrm{ppm}$ for $36 \mathrm{~h}$ (9\%) (Fig. 1[A]).

The results of normal seedling percentage (NSP) under free ageing are similar to GP (Fig. 1[B]). Seed priming with BAP $25 \mathrm{ppm}$ for $24 \mathrm{~h}$ resulted in a statistically significant increase in NSP under three (77\%) and six (40\%) days of ageing, whereas in the same conditions, unprimed seeds'
NSP were respectively 57 and 17 percent (Fig. 1[B]). Seed priming with BAP $25 \mathrm{ppm}$ for 24 and $36 \mathrm{~h}$ performed prior to accelerated ageing, increased the Timson index (GI) (Fig. $1[\mathrm{C}]$ ). At three days AA, the highest and the lowest GI was assigned for BAP 25 and $50 \mathrm{ppm}$ for $24 \mathrm{~h}(\mathrm{GI}=14)$ and unprimed $(\mathrm{GI}=6.7 \%)$ respectively (Fig. $1[\mathrm{C}])$. Seed priming with the BAP 25 and $50 \mathrm{ppm}$ for 24 and $36 \mathrm{~h}$ led to a decreased SVI of seeds tested under optimum temperature conditions (Fig. 1[D]). However, on three days of AA, BAP $25 \mathrm{ppm}$ for $24 \mathrm{~h}$ had a higher SVI compared to unprimed seeds (Fig. 1[D]). In addition, for BAP 25 and 50 ppm for $36 \mathrm{~h}$ there were no significantly differences compared with
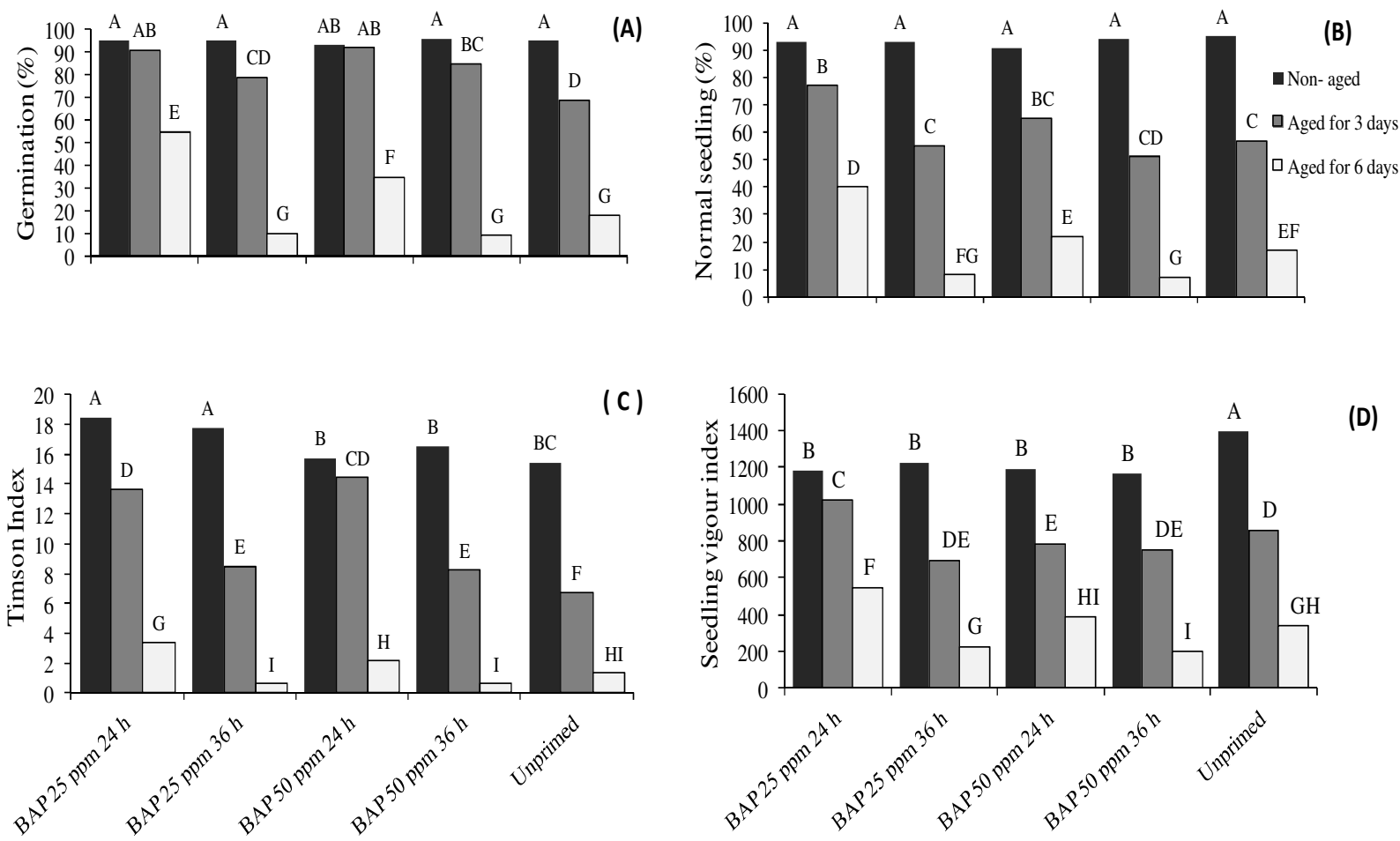

(D)

Fig. 1. Germination (\%) (A), normal seedling (\%) (B), Timson index (C) and seedling vigour index (D) of unprimed and primed Tall wheatgrass seeds subjected to 0,3 and 6 days accelerated aging. Priming treatments were BAP 25 and 50 ppm for 24 and 36 h at $10^{\circ} \mathrm{C}$

the unprimed seeds. Furthermore, at the six days AA, BAP $25 \mathrm{ppm}$ for $24 \mathrm{~h}$ had a higher SVI compared to unprimed seeds $(\mathrm{P}<0.05)$ (Fig. 1[D]).

\section{Accelerated Ageing after Post-Priming (Heat Shock)}

Analysis of variance of accelerated ageing followed by post-priming revealed that there is a significant difference between the primed seeds exposed to different temperature and the duration of the heat shock $(\mathrm{P}<0.0001)$. The triple interactions between priming, heat shock and AA was significant for all traits (NSP: F-Value $=6.36, \mathrm{P}<0.0001$; SVI: F-Value $=4.61, \mathrm{P}<0.0001$ and GI: F-Value $=14.57, \mathrm{P}$ $<0.0001)$. Comparison of means with Duncan's multiple range test illustrated that under free $\mathrm{AA}$, priming treatments at different levels of heat shock, had no significant differences.

The greatest differences were observed in the three and six days of AA. Therefore, the results of three and six days of AA may suffice (Tab. 1). At three days of AA, heat shock of $40^{\circ} \mathrm{C}$ in all four-term, followed by priming treatments, gave higher NSP (Tab. 1), while the lowest belonged to heat shock of $30{ }^{\circ} \mathrm{C}$. The highest NSP $(83 \%)$ was assigned to heat shock of $40{ }^{\circ} \mathrm{C}$ for four hours, followed by BAP 50 ppm for $24 \mathrm{~h}$ (Tab. 1). In addition, heat shock of $40{ }^{\circ} \mathrm{C}$ for periods of 1 and 4 hours, followed by BAP $25 \mathrm{ppm}$ for $24 \mathrm{~h}$ and $40^{\circ} \mathrm{C}$ for $2 \mathrm{~h}, \mathrm{BAP} 25 \mathrm{ppm}$ for $36 \mathrm{~h}$, were the best in terms of NSP (Tab. 1). Seeds primed with BAP 25 and 50 ppm for $24 \mathrm{~h}$ exposed to heat shock of 30 and $40{ }^{\circ} \mathrm{C}$ in the all four-term samples had higher GI under free ageing (Tab. 2). However, all levels of heat shock drastically reduced GI primed seeds at BAP for $36 \mathrm{~h}$ (Tab. 2). Accelerated ageing resulted in a statistically significant reduction in GI and SVI (Tab. 2 and Tab. 3). So that, by increasing the aging period, GI and SVI felt heavily. Nevertheless, heat shock of $40{ }^{\circ} \mathrm{C}$ 
Tab. 1. Normal seedling percentage of Tall wheatgrass seeds at different levels of heat shock followed by priming treatments; the $\mathrm{LSD}_{0.05}$ for normal seedling $(\%)$ is 7.745

\begin{tabular}{|c|c|c|c|c|c|}
\hline \multirow{2}{*}{ Priming treatments } & \multicolumn{2}{|c|}{$\begin{array}{c}\text { Heat shock after } \\
\text { priming }\end{array}$} & \multicolumn{3}{|c|}{ Days of ageing } \\
\hline & $\begin{array}{c}\text { Temp } \\
\left({ }^{\circ} \mathrm{C}\right)\end{array}$ & $\begin{array}{c}\text { Time } \\
\text { (h) }\end{array}$ & 0 & 3 & 6 \\
\hline \multirow{8}{*}{ BAP $25 \mathrm{ppm} 24 \mathrm{~h}$} & \multirow{4}{*}{30} & 1 & $92(5)^{A-D}$ & $65(10)^{\mathrm{M}-\mathrm{T}}$ & $9(5)^{d-f}$ \\
\hline & & 2 & $95(3)^{\mathrm{AB}}$ & $23(5)^{z \cdot b}$ & $9(3)^{d-f}$ \\
\hline & & 3 & $94(3)^{\mathrm{AB}}$ & $30(17)^{\mathrm{Y}-\mathrm{a}}$ & $6(6)^{\mathrm{d}-\mathrm{g}}$ \\
\hline & & 4 & $89(4)^{A \cdot G}$ & $36(22)^{x-z}$ & $4(3) e-i$ \\
\hline & \multirow{4}{*}{40} & 1 & $91(4)^{\mathrm{A}-\mathrm{E}}$ & $78(10)^{\mathrm{F}-\mathrm{M}}$ & $57(5)^{\mathrm{Q}-\mathrm{V}}$ \\
\hline & & 2 & $96(2)^{A}$ & $61(2)^{\mathrm{O}-\mathrm{V}}$ & $9(5)^{d-f}$ \\
\hline & & 3 & $93(2)^{A-C}$ & $77(6)^{\mathrm{G}-\mathrm{N}}$ & $9(7)^{\mathrm{d}-\mathrm{f}}$ \\
\hline & & 4 & $91(5)^{\mathrm{A}-\mathrm{E}}$ & $80(7)^{\mathrm{F}-\mathrm{L}}$ & $46(4)^{v-x}$ \\
\hline \multirow{8}{*}{ BAP $25 \mathrm{ppm} 36 \mathrm{~h}$} & \multirow{4}{*}{30} & 1 & $88(2)^{A-H}$ & $58(9)^{\text {p.V }}$ & $1(2)^{h-j}$ \\
\hline & & 2 & $89(6)^{A \cdot F}$ & $11(5)^{c-e}$ & $1(1)^{i j}$ \\
\hline & & 3 & $90(2)^{A-F}$ & $61(8)^{\mathrm{O}-\mathrm{V}}$ & $5(5)^{e-i}$ \\
\hline & & 4 & $89(3)^{A-G}$ & $39(5)^{W \cdot Y}$ & $5(3)^{d-h}$ \\
\hline & \multirow{4}{*}{40} & 1 & $83(3)^{\mathrm{D}-\mathrm{K}}$ & $67(1)^{\mathrm{L}-\mathrm{S}}$ & $7(2)^{\mathrm{d}-\mathrm{g}}$ \\
\hline & & 2 & $87(3)^{\mathrm{B} \cdot \mathrm{H}}$ & $80(6)^{\mathrm{F}-\mathrm{L}}$ & $5(5)^{e-i}$ \\
\hline & & 3 & $90(2)^{A-F}$ & $59(9)^{P-V}$ & $5(5)^{d-i}$ \\
\hline & & 4 & $88(4)^{A-H}$ & $71(15)^{\mathrm{J}-\mathrm{R}}$ & $0(0)^{i}$ \\
\hline \multirow{8}{*}{ BAP $50 \mathrm{ppm} 24 \mathrm{~h}$} & \multirow{4}{*}{30} & 1 & $93(5)^{A-D}$ & $63(4)^{N-U}$ & $5(4)^{d-h}$ \\
\hline & & 2 & $70(5)^{\mathrm{K}-\mathrm{R}}$ & $47(5)^{\mathrm{U} \cdot \mathrm{x}}$ & $2(2)^{g-i}$ \\
\hline & & 3 & $95(3)^{\mathrm{AB}}$ & $47(8)^{\mathrm{U}-\mathrm{x}}$ & $6(2)^{\mathrm{d}-\mathrm{g}}$ \\
\hline & & 4 & $89(4)^{A-F}$ & $39(2)^{\mathrm{W}-\mathrm{Y}}$ & $6(3)^{d-g}$ \\
\hline & \multirow{4}{*}{40} & 1 & $81(3)^{\mathrm{F}-\mathrm{L}}$ & $49(8)^{\mathrm{T}-\mathrm{X}}$ & $7(1)^{\mathrm{d}-\mathrm{g}}$ \\
\hline & & 2 & $80(6)^{\mathrm{F}-\mathrm{L}}$ & $56(9)^{R-V}$ & $21(1)^{a-c}$ \\
\hline & & 3 & $89(4)^{A-G}$ & $72(0)^{\mathrm{J}-\mathrm{O}}$ & $13(1)^{b-d}$ \\
\hline & & 4 & $85(8)^{\mathrm{B}-\mathrm{I}}$ & $83(11)^{\mathrm{C}-\mathrm{K}}$ & $8(2)^{d-f}$ \\
\hline \multirow{8}{*}{ BAP $50 \mathrm{ppm} 36 \mathrm{~h}$} & \multirow{4}{*}{30} & 1 & $77(6)^{\mathrm{G}-\mathrm{N}}$ & $60(9)^{\mathrm{P}-\mathrm{V}}$ & $2(0)^{f_{-j}}$ \\
\hline & & 2 & $73(4)^{\mathrm{L}-\mathrm{P}}$ & $63(15)^{N-U}$ & $11(2)^{c-e}$ \\
\hline & & 3 & $84(2)^{\mathrm{C}-\mathrm{J}}$ & $58(6)^{\mathrm{P}-\mathrm{V}}$ & $1(1)^{i j}$ \\
\hline & & 4 & $75(8)^{\mathrm{H}-\mathrm{O}}$ & $46(7)^{v-x}$ & $0(0)^{i}$ \\
\hline & \multirow{4}{*}{40} & 1 & $78(4)^{\mathrm{F}-\mathrm{M}}$ & $53(9)^{\text {S.W }}$ & $5(1)^{\mathrm{d}-\mathrm{g}}$ \\
\hline & & 2 & $78(7)^{\mathrm{F}-\mathrm{M}}$ & $52(3)^{5 . W}$ & $6(4)^{\mathrm{d}-\mathrm{g}}$ \\
\hline & & 3 & $83(4)^{\mathrm{D}-\mathrm{K}}$ & $57(6)^{\text {P.V }}$ & $0(0)^{i}$ \\
\hline & & 4 & $89(3)^{A-G}$ & $65(2)^{\mathrm{M}-\mathrm{T}}$ & $2(2)^{g-j}$ \\
\hline
\end{tabular}

Under free ageing, SVI of primed seeds with BAP 50 ppm exposed to heat shock in the all four-term samples had lower values. The result of SVI is similar to GI (Tab. 3). So that, at six days of AA, heat shock of $40^{\circ} \mathrm{C}$ for periods of 1 and 4 hours, followed by BAP $25 \mathrm{ppm}$ for $24 \mathrm{~h}$, had higher SVI, respectively 877 and 748 (Tab. 3).

The response of unshocked and shocked priming treatments was different among samples, in regard to AA. Applying different levels of heat shock led to considerable variation in the amount of GP. Although the comparison between unshocked and shocked priming treatments was not performed, with a glimpse of data, it can be said that in three days of AA, at most levels of heat shock treatments, followed by priming, NSP not only did not decrease, but even increased in some cases. For example, in heat shock of $40{ }^{\circ} \mathrm{C}$ for 4 hours, followed by BAP $50 \mathrm{ppm}$ for $24 \mathrm{~h}$, NSP was $83 \%$ (Tab. 1), while in unprimed seeds it was $57 \%$ (Fig $1[B])$. In the case of GI and SVI also, the same results were obtained. At six days of AA, GP, NSP, GI and SVI of all priming treatments, at all levels of heat shock, dramatically decreased (Tab. 1, Tab.2, Tab. 3), except for heat shock of $40{ }^{\circ} \mathrm{C}$ for periods 1 and 4 hours, followed by BAP $25 \mathrm{ppm}$ for $24 \mathrm{~h}$. This information suggests that many factors can be effective in inducing storability of primed seeds, and in fact, in maintaining the desirable properties of priming. The type of material and their concentrations, temperature and duration of priming, and also temperature and duration of heat shock, were all involved in providing different responses. However, most aging studies have been conducted on primed seeds with different materials and methods, and have revealed that priming often reduces seed longevity (Bruggink et al., 1999; Gurusinghe and Bradford, 2001; Lin et al., 2005). This study was also no exception from this rule. During the last decade, some researchers were trying to use different post-priming methods, to return longevity of primed seeds. In the study of Bruggink et al. (1999), it was used PEG incubation of primed seeds for 3 days and heat shock $\left(40^{\circ} \mathrm{C}\right)$ treatment for $3 \mathrm{~h}$, and was able by this manner to prevent the reduction of longevity. Lin et al. (2005) concluded that while slow drying improved the initial quality of primed seeds, on the contrast, fast drying led to a rapid reduction of seed longevity during storage. In their study, slow-dried seeds initially accumulated less amounts of MDA and total peroxide, as compared to fastdried seeds. The results obtained from our study showed that after six days of AA, the GI of 3.3 was obtained for unshocked BAP $25 \mathrm{ppm}$ for $24 \mathrm{~h}$ priming (Fig. 1[C]). But under the shock of $40^{\circ} \mathrm{C}$ for 1 and $4 \mathrm{~h}, \mathrm{GI}$ increased to 6.8 and 7.2, respectively (Tab. 2), whereas GI of the control (unprimed) was 1.3 (Fig. 1[C]). Furthermore, as mentioned in results for AA, the SVI of 547 was obtained for unshocked BAP $25 \mathrm{ppm}$ for $24 \mathrm{~h}$ priming (Fig. 1[D]). But treated with the heat shock of $40^{\circ} \mathrm{C}$ for 1 and $4 \mathrm{~h}$, SVI increased to 877 and 748 , respectively (Tab. 3), while SVI of 339 was obtained for the control (Fig. 1[D]). The similarity in inductive methods for desiccation tolerance in germinated seeds, and for storability in primed seeds, suggests that the same physiological mechanisms are involved (Bruggink et al., 1999). Desiccation tolerance of seeds is a complex multifactorial trait, involving a multitude of genes, whose expression ultimately leads to mechanisms of both cellular protection and cellular repair (Gallardo et al., 2001). Tikhomirova (1985) expressed that in Pennisetum glaucum, pre-sowing hardening of the seeds at $42{ }^{\circ} \mathrm{C}$ resulted in plants' tolerance to overheating and dehydration and also in having higher levels of water-soluble proteins and lower amounts of amide-N, compared to nonhardened plants. In the process of heat acclimatization, heat shock factors (Hsfs) play an important role in regulation of this heat-induced transcriptional reprogramming (Kotak et al., 2007). Immediately after exposure to heat shocks and perception of signals, changes occur at molecular level, altering the expression of genes, and the accumulation of transcripts, therefore leading to the synthesis of stress induced proteins, as a heat-tolerance strategy (Iba, 2002). The production of heat shock proteins (HSPs) is known to be a significant adaptive strategy in this regard. The HSPs have chaperone-like functions and are involved in signal transduction during heat shock (Wahid et al., 2007). Additionally, there are specified late embryogenesis abundant (LEA) proteins genes that are induced in vegetative tissues, in response to high temperatures, drought and salinity stress, or by exogenous ABA (Tunnadiffe and Wise, 2007; Bies-Etheve et al., 2008). Other studies (Clarke et al., 2004 and 2009; Larkindale and Knight, 2002; Larkindale et al., 2005) shed some light on crosstalk between the hormonal, redox and calcium-activated, signaling pathways which can play a significant role in heat- 
260

tolerance, to ensure a rapid response, which is essential for survival against heat shock. During recent years, there has been increasing evidence on the role of salicylic acid (SA) in acquiring tolerance mechanisms for several abiotic stress conditions (Horvath et al., 2007). It has also been suggested that SA is to be involved in heat-shock responses (Liu et al., 2006; Clarke et al., 2009). In report of Alonso-Ramirez et al. (2009) it became clear that the overexpression of a FsGASA4 (gene from Fagus sylvatica) in Arabidopsis improves plant tolerance to heat shock, through had an increase in SA biosynthesis. On the other hand, overexpression of FsGASA4 in Arabidopsis induces high tolerance to paclobutrazol (GA biosynthesis inhibitor) and reduces the dependence of GA for growing (AlonsoRamirez et al., 2009). Heckman et al. (2002) pointed that Kentucky bluegrass (Poa pratensis) plants treated with a GA inhibitor were less heat tolerant than untreated plants. In addition, the overexpression of a GASA4 in Arabidopsis induces resistance to heat shock (Ko et al., 2007). In report of Alonso-Ramirez et al. (2009) the exogenous application of GA3 was able to reverse the inhibitory effect of heat stress in Arabidopsis seedlings. Findings of current study are consistent with those of Alonso-Ramirez et al. (2009). Larkindale et al. (2005) observed an increase in the level of absicic acid (ABA) upon recovery from heat shock, suggesting a key role at the latter period. ABA is an inductor of acclimation/adaptation in plants, also influencing desiccation by modulating the up- or down-regulation of

Tab. 2. Timson index (GI) of Tall wheatgrass seeds at different levels of heat shock followed by priming treatments; the

\begin{tabular}{|c|c|c|c|c|c|}
\hline \multirow{2}{*}{ Priming treatments } & \multicolumn{2}{|c|}{$\begin{array}{l}\text { Heat shock after } \\
\text { priming }\end{array}$} & \multicolumn{3}{|c|}{ Days of ageing } \\
\hline & $\begin{array}{l}\text { Temp } \\
\left({ }^{\circ} \mathrm{C}\right)\end{array}$ & $\begin{array}{l}\text { Time } \\
\text { (h) }\end{array}$ & 0 & 3 & 6 \\
\hline \multirow{8}{*}{ BAP $25 \mathrm{ppm} 24 \mathrm{~h}$} & \multirow{4}{*}{30} & 1 & $19(0.7)^{\mathrm{B}-\mathrm{D}}$ & $10(0.7)^{\mathrm{NO}}$ & $0.9(0.4)^{\mathrm{YZ}}$ \\
\hline & & 2 & $21(0.3)^{\mathrm{A}}$ & $8(1.1)^{\mathrm{P} \cdot \mathrm{T}}$ & $1.1(0.5)^{\mathrm{YZ}}$ \\
\hline & & 3 & $19(1.2)^{\mathrm{BD}}$ & $11(2.6)^{\mathrm{L}-\mathrm{N}}$ & $0.7(0.5)^{\mathrm{YZ}}$ \\
\hline & & 4 & $19(1.4)^{\mathrm{BC}}$ & $7(0.6)^{\mathrm{SU}}$ & $0.8(0.9)^{\mathrm{YZ}}$ \\
\hline & \multirow{4}{*}{40} & 1 & $20(0.9)^{\mathrm{AB}}$ & $11(0.2)^{\mathrm{K} \cdot \mathrm{M}}$ & $6.8(1)^{\mathrm{T} V \mathrm{~V}}$ \\
\hline & & 2 & $19(0.6)^{\mathrm{BC}}$ & $10(0.5)^{\mathrm{NO}}$ & $1.1(0.6)^{\mathrm{YZ}}$ \\
\hline & & 3 & $18(0.9)^{\mathrm{CE}}$ & $13(0.6)^{1-\mathrm{K}}$ & $1.7(1)^{\mathrm{x} \cdot \mathrm{Z}}$ \\
\hline & & 4 & $18(0.7)^{\mathrm{CE}}$ & $15(1.1)^{\mathrm{F}}$ & $7.2(1.2)^{\mathrm{su}}$ \\
\hline \multirow{8}{*}{ BAP $25 \mathrm{ppm} 36 \mathrm{~h}$} & \multirow{4}{*}{30} & 1 & $10(0.5)^{\mathrm{MN}}$ & $8(0.2)^{S T}$ & $1.2(0.4)^{\mathrm{YZ}}$ \\
\hline & & 2 & $11(0.6)^{\mathrm{K}-\mathrm{M}}$ & $3(0.2)^{\mathrm{x}}$ & $0.2(0.1)^{\mathrm{z}}$ \\
\hline & & 3 & $10(1.2)^{\mathrm{NQ}}$ & $7(0.7)^{\mathrm{sU}}$ & $0.7(0.4)^{\mathrm{YZ}}$ \\
\hline & & 4 & $12(0.5)^{\mathrm{HL}}$ & $7(0.1)^{\mathrm{sU}}$ & $0.6(0.2)^{\mathrm{YZ}}$ \\
\hline & \multirow{4}{*}{40} & 1 & $12(0.7)^{\mathrm{K} \cdot \mathrm{M}}$ & $10(0.3)^{\mathrm{NO}}$ & $1(0.2)^{Y Z}$ \\
\hline & & 2 & $13(0.7)^{\mathrm{H}-\mathrm{K}}$ & $8.1(1.5)^{\mathrm{QT}}$ & $0.4(0.4)^{\mathrm{z}}$ \\
\hline & & 3 & $12(1.2)^{\mathrm{GJ} J}$ & $9.5(0.7)^{\mathrm{NQ}}$ & $0.8(0.3)^{\mathrm{YZ}}$ \\
\hline & & 4 & $13(1)^{\mathrm{LK}}$ & $10.2(0.1)^{\mathrm{MN}}$ & $0.3(0.2)^{\mathrm{z}}$ \\
\hline \multirow{8}{*}{ BAP $50 \mathrm{ppm} 24 \mathrm{~h}$} & \multirow{4}{*}{30} & 1 & $18(0.2)^{\mathrm{CE}}$ & $11(0.4)^{\mathrm{K} M}$ & $0.5(0.3)^{\mathrm{z}}$ \\
\hline & & 2 & $18(0.7)^{\mathrm{E}}$ & $9(1.1)^{\mathrm{N}-\mathrm{R}}$ & $0.2(0.2)^{z}$ \\
\hline & & 3 & $19(0.3)^{\mathrm{BE}}$ & $10(1.3)^{N Q Q}$ & $0.6(0.1)^{\mathrm{z}}$ \\
\hline & & 4 & $19(0.9)^{\mathrm{BC}}$ & $10(0.6)^{N-Q}$ & $1.3(0.7)^{\mathrm{YZ}}$ \\
\hline & \multirow{4}{*}{40} & 1 & $18(1.6)^{\mathrm{CE}}$ & $10(1.2)^{\mathrm{NO}}$ & $0.5(0.1)^{\mathrm{z}}$ \\
\hline & & 2 & $18(0.7)^{\mathrm{DE}}$ & $10(1)^{\mathrm{NP}}$ & $2.2(0.4)^{\mathrm{XY}}$ \\
\hline & & 3 & $19(0.6)^{\mathrm{BD}}$ & $14(0.7)^{\mathrm{FH}}$ & $0.9(0.1)^{\mathrm{YZ}}$ \\
\hline & & 4 & $19(0.6)^{\mathrm{BE}}$ & $13(1.7)^{1-\mathrm{K}}$ & $1.1(0.6)^{\mathrm{YZ}}$ \\
\hline \multirow{8}{*}{ BAP $50 \mathrm{ppm} 36 \mathrm{~h}$} & \multirow{4}{*}{30} & 1 & $3(1)^{\mathrm{X}}$ & $7.5(0.7)^{\mathrm{SU}}$ & $0.4(0.1)^{\mathrm{z}}$ \\
\hline & & 2 & $11(0.6)^{\mathrm{LN}}$ & $9.4(0.6)^{\mathrm{N}-\mathrm{R}}$ & $1.5(0.3)^{\mathrm{rz}}$ \\
\hline & & 3 & $12(0.3)^{\mathrm{K}-\mathrm{M}}$ & $8.5(0.7)^{\mathrm{O} S}$ & $0.4(0.2)^{\mathrm{z}}$ \\
\hline & & 4 & $15(1)^{\mathrm{FG}}$ & $5.3(0.5)^{\mathrm{W}}$ & $0.3(0.2)^{\mathrm{z}}$ \\
\hline & \multirow{4}{*}{40} & 1 & $14(1.1)^{\mathrm{FJ}}$ & $6.1(0.7)^{\text {U.W }}$ & $0.5(0.2)^{\mathrm{z}}$ \\
\hline & & 2 & $11(1.4)^{L N}$ & $8(1)^{R \cdot T}$ & $0.7(0.7)^{\mathrm{YZ}}$ \\
\hline & & 3 & $13(0.4)^{1-\mathrm{K}}$ & $8.4(1.2)^{\mathrm{os}}$ & $0.4(0.2)^{\mathrm{z}}$ \\
\hline & & 4 & $14(0.7)^{\mathrm{F}-\mathrm{I}}$ & $5.6(0.6)^{\mathrm{VW}}$ & $0.5(0.4)^{\mathrm{z}}$ \\
\hline
\end{tabular}

Note: Means $( \pm \mathrm{SD})$ without the same lowercases indicate statistically significant differences for Timson index $(\mathrm{P}<0.05)$. abundant genes (Xiang et al., 2002). These approaches reflect a complex cross-talk among different hormones at both levels of biosynthesis and action (Weiss and Ori, 2007). There are specified LEA genes that are induced in vegetative tissues in response to high temperatures, drought, salinity stress or by exogenous ABA (Tunnadiffe and Wise, 2007; Bies-Etheve et al., 2008). However, BAP hormone has not been used for this purpose to date.

Tab. 3. Seedling vigour index (SVI) of Tall wheatgrass seeds at different levels of heat shock followed by priming treatments; the LSD0.05 for SVI is 174.32

\begin{tabular}{|c|c|c|c|c|c|}
\hline \multirow{2}{*}{$\begin{array}{c}\text { Priming } \\
\text { treatments }\end{array}$} & \multicolumn{2}{|c|}{$\begin{array}{l}\text { Heat shock after } \\
\text { priming }\end{array}$} & \multicolumn{3}{|c|}{ Days of ageing } \\
\hline & $\begin{array}{l}\text { Temp } \\
\left({ }^{\circ} \mathrm{C}\right)\end{array}$ & $\begin{array}{l}\text { Time } \\
\text { (h) }\end{array}$ & 0 & 3 & 6 \\
\hline \multirow{8}{*}{ BAP $25 \mathrm{ppm} 24 \mathrm{~h}$} & \multirow{4}{*}{30} & 1 & $1195(76)^{A-C}$ & $716(78)^{\mathrm{M}-\mathrm{Q}}$ & $272(81)^{\mathrm{U}-\mathrm{b}}$ \\
\hline & & 2 & $1203(82)^{A-C}$ & $414(25)^{5 \cdot x}$ & $278(50)^{\mathrm{U}-\mathrm{b}}$ \\
\hline & & 3 & $1140(80)^{A-D}$ & $443(168)^{S V V}$ & $232(96)^{\mathrm{W} / c}$ \\
\hline & & 4 & $1085(80)^{A \cdot G}$ & $502(202)^{R-T}$ & $186(85)^{\mathrm{Y}-\mathrm{d}}$ \\
\hline & \multirow{4}{*}{40} & 1 & $1022(144)^{\mathrm{BJ}}$ & $908(117)^{\mathrm{ELL}}$ & $877(14)^{\mathrm{G}-\mathrm{O}}$ \\
\hline & & 2 & $1291(157)^{A}$ & $663(62)^{\mathrm{OR}}$ & $285(68)^{\mathrm{U}-\mathrm{a}}$ \\
\hline & & 3 & $1200(131)^{A C C}$ & $904(89)^{\mathrm{FM}}$ & $289(136)^{\mathrm{Ua}}$ \\
\hline & & 4 & $1067(171)^{\mathrm{BH}}$ & $954(50)^{\mathrm{DL}}$ & $748(109)^{L-O}$ \\
\hline \multirow{8}{*}{ BAP $25 \mathrm{ppm} 36 \mathrm{~h}$} & \multirow{4}{*}{30} & 1 & $1148(11)^{A-D}$ & $824(125)^{\mathrm{K}-\mathrm{O}}$ & $64(111)^{\mathrm{bdd}}$ \\
\hline & & 2 & $1197(191)^{A C C}$ & $322(70)^{\mathrm{T} \cdot \mathrm{Z}}$ & $0(0)^{d}$ \\
\hline & & 3 & $1156(143)^{A-D}$ & $899(100)^{\mathrm{EM}}$ & $162(157)^{\mathrm{Y}-\mathrm{d}}$ \\
\hline & & 4 & $1148(38)^{A-D}$ & $703(62)^{\mathrm{M}-\mathrm{R}}$ & $187(52)^{Y-d}$ \\
\hline & \multirow{4}{*}{40} & 1 & $1055(64)^{\mathrm{BH}}$ & $1044(105)^{\mathrm{BI}}$ & $227(27)^{\mathrm{W}-c}$ \\
\hline & & 2 & $1121(90)^{\mathrm{AEE}}$ & $1149(153)^{A-D}$ & $160(149)^{Y-d}$ \\
\hline & & 3 & $1231(125)^{\mathrm{AB}}$ & $884(93)^{\mathrm{GN}}$ & $192(108)^{Y-d}$ \\
\hline & & 4 & $1150(88)^{A-D}$ & $1086(301)^{A-G}$ & $0(0)^{d}$ \\
\hline \multirow{8}{*}{ BAP $50 \mathrm{ppm} 24 \mathrm{~h}$} & \multirow{4}{*}{30} & 1 & $907(81)^{\mathrm{EL}}$ & $702(35)^{\mathrm{M}-\mathrm{R}}$ & $217(93)^{X_{c}}$ \\
\hline & & 2 & $710(33)^{\mathrm{M}-\mathrm{Q}}$ & $586(66)^{e s}$ & $111(101)^{\mathrm{Zd}}$ \\
\hline & & 3 & $1046(174)^{\mathrm{B}-\mathrm{I}}$ & $555(62)^{\mathrm{Q} . S}$ & $230(38)^{\mathrm{W} c}$ \\
\hline & & 4 & $832(61)^{10}$ & $468(39)^{\mathrm{SU}}$ & $216(46)^{x_{c}}$ \\
\hline & \multirow{4}{*}{40} & 1 & $872(178)^{\mathrm{G} \cdot \mathrm{O}}$ & $677(50)^{N-R}$ & $255(22)^{V_{c}}$ \\
\hline & & 2 & $964(185)^{\mathrm{DL}}$ & $715(93)^{\mathrm{M}-\mathrm{Q}}$ & $436(21)^{S-W}$ \\
\hline & & 3 & $1052(185)^{\mathrm{BH}}$ & $746(35)^{L-Q}$ & $344(4)^{\mathrm{T} Y}$ \\
\hline & & 4 & $1054(272)^{\mathrm{BH}}$ & $1000(163)^{\mathrm{CJ}}$ & $257(64)^{V_{c}}$ \\
\hline \multirow{8}{*}{ BAP $50 \mathrm{ppm} 36 \mathrm{~h}$} & \multirow{4}{*}{30} & 1 & $778(111)^{\mathrm{K} \cdot \mathrm{P}}$ & $894(152)^{\mathrm{EN}}$ & $112(7)^{\mathrm{Zd}}$ \\
\hline & & 2 & $859(134)^{\mathrm{Ho}}$ & $895(129)^{\mathrm{EM}}$ & $304(36)^{\mathrm{T}-\mathrm{Z}}$ \\
\hline & & 3 & $1066(93)^{\mathrm{BH}}$ & $823(110)^{\mathrm{K}-\mathrm{O}}$ & $42(73)^{\mathrm{cd}}$ \\
\hline & & 4 & $994(168)^{C K}$ & $698(94)^{\mathrm{M}-\mathrm{R}}$ & $0(0)^{d}$ \\
\hline & \multirow{4}{*}{40} & 1 & $947(96)^{\mathrm{DL}}$ & $833(59)^{\mathrm{LO}}$ & $208(26)^{x d}$ \\
\hline & & 2 & $1111(100)^{A-F}$ & $819(45)^{\mathrm{K} O \mathrm{O}}$ & $219(94)^{X_{c}}$ \\
\hline & & 3 & $1036(124)^{\mathrm{BJ}}$ & $867(33)^{\mathrm{GO}}$ & $0(0)^{\mathrm{d}}$ \\
\hline & & 4 & $1122(102)^{\mathrm{AE}}$ & $903(20)^{\mathrm{EM}}$ & $77(75)^{2 \cdot d}$ \\
\hline
\end{tabular}
significant differences for seedling vigour index $(\mathrm{P}<0.05)$.

\section{Conclusions}

In conclusion, the results described here re-confirm that priming improves the initial quality of Tall wheatgrass seeds. The method of heat shock followed by priming also affects the initial quality of primed seeds. As mentioned above, the shock of $40^{\circ} \mathrm{C}$ for 1 and $4 \mathrm{~h}$ was able to improve longevity in primed seeds with BAP $25 \mathrm{ppm}$ for $24 \mathrm{~h}$. Although we could not investigate the molecular dimensions of these treatments, the similarity in induction methods for heat tolerance in germinated seeds (or different plant organs) and for longevity in primed seeds, suggests that the same physiological mechanisms are involved. Future researches, with more focus on validating heat shock effects on storability of primed seeds, are therefore suggested. By studying the physiological and molecular mechanisms involved in these processes, a large number of questions can be answered.

\section{References}


Abdul-Baki AA, Anderson JD (1973). Vigor determination in soybean by multiple criteria. Crop Sci (13):630-633.

Alonso-Ramirez A, Rodriguez D, Reyes D, Jimenez JA, Nicolas G, Lopez-Climent M, Gomez-Cadenas A, Nicolas C (2009). Evidence for a Role of Gibberellins in Salicylic Acid-Modulated Early Plant Responses to Abiotic Stress in Arabidopsis Seeds. Plant Physiology 150:1335-1344.

Bies-Etheve N, Gaubier Comella P, Debures A, Lasserre E, Jobet E, Raynal M, Cooke R, Delseny M (2008). Inventory, evolution and expression profiling diversity of the LEA (Late embryogenesis abundant) protein gene family in Arabidopsis thaliana. Plant Mol Biol 67:107-124.

Bruggink GT, Ooms JJJ, Van der Toorn P (1999). Induction of longevity in primed seeds. Seed Sci Res 9:49-53.

Butler LH, Hay FR, Ellis RH, Smith RD, Murray TB (2009). Priming and re-drying improve the survival of mature seeds of Digitalis purpurea during storage. Ann Bot 103:1261-1270.

Delouche JC, Baskin CC (1973). Accelerated ageing techniques for predicting the relative storability of seed lots. Seed Science and Technology 1:427-52.

Farooq M, Aziz T, Basra SMA, Cheema MA, Rehman H (2008). Chilling tolerance in hybrid maize induced by seed priming with salicylic acid. Journal Agronomy and Crop Science 194:161-168.

Gallardo K, Job C, Groot SPC, Puype M, Demol H, Vandekerckhove J, Job D (2001). Proteomic analysis of Arabidopsis seed germination and priming. Plant Physiol 126:835-848.

Gurusinghe S, Bradford KJ (2001). Galactosyl-sucrose oligosaccharides and potential longevity of primed seeds. Seed Science Research 11:121-133.

Heckman NL, Horst GL, Gaussoin RE, Tavener BT (2002). Trinexapacethyl influence on cell membrane thermostability of Kentucky bluegrass leaf tissue. Sci Hortic (Amsterdam) 92:183186.

Horvath E, Szalai G, Janda T (2007). Induction of abiotic stress tolerance by salicylic acid signaling. J Plant Growth Regul 26:290-300.

Iba K (2002). Acclimative response to temperature stress in higher plants: approaches of gene engineering for temperature tolerance. Annu Rev Plant Biol 53:225-245.

Iqbal M, Ashraf M (2007). Seed preconditioning modulates growth, ionic relations, and photosynthetic capacity in adult plants of hexaploid wheat under salt stress. Journal of Plant Nutrition 30:381-396.

ISTA (1996). Rules for Seed Testing. International Seed Testing Association (ISTA), Zurich, Switzerland.

ISTA (2010). International Rules for Seed Testing, International Seed Testing Association (ISTA), Zurich, Switzerland.

Ko CB, Woo YM, Lee DJ, Lee MC, Kim CS (2007). Enhanced tolerance to heat stress in transgenic plants expressing the GASA4 gene. Plant Physiol Biochem 45:722-728.

Korkmaz A, Korkmaz Y (2009). Promotion by 5-aminolevulenic acid of pepper seed germination and seedling emergence under low-temperature stress. Scientia Horticulturae 119:98-102.

Kotak S, Larkindale J, Lee U, von Koskull-Döring P, Vierling E, Scharf KD (2007). Complexity of the heat stress response in plants. Current Opinion in Plant Biology 10:310-316.

Kruse M (1999). Application of the normal distribution for testing the potential of the controlled deterioration test. Crop Science 39:1125-1129.

Larkindale J, Knight MR (2002). Protection against heat stressinduced oxidative damage in Arabidopsis involves calcium, abscisic acid, ethylene, and salicylic acid. Plant Physiol 128:682695.

Larkindale J, Hall JD, Knight MR, Vierling E (2005). Heat stress phenotypes of Arabidopsis mutants implicate multiple signaling pathways in the acquisition of thermotolerance. Plant Physiol 138:882-897.

Lin RH, Chen KY, Chen CL, Chen JJ, Sung JM (2005). Slow posthydration drying improves initial quality but reduces longevity of primed bitter gourd seeds. Scientia Horticulturae 106:114124.

Liu H-T, Liu Y-Y, Pan Q-H, Yang H-R, Zhan Ji-CH, Huang W-D (2006). Novel interrelationship between salicylic acid, abscisic acid, and PIP2-specific phospholipase C in heat acclimationinduced thermotolerance in pea leaves. Journal of Experimental Botany 57:3337-3347.

McDonald MB (1999). Seed deterioration: physiology, repair and assessment, Seed Sci Technol 27:177-237.

Tikhomirova EV (1985). Changes of nitrogen metabolism in millet at elevated temperatures. Field Crops Research 11:259-264.

Tunnacliffe A, Wise MJ (2007). The continuing conundrum of LFA proteins. Naturwissenschaften 94:791-812.

Wahid A, Gelani S, Ashraf M, Foolad MR (2007). Heat tolerance in plants: an overview. Environmental and Experimental Botany 61:199-223.

Wain-Tassi AL, Santos JFD, Panizzi RDC, Vieira RD (2012). Seedborne pathogens and electrical conductivity of soybean seeds. Scientia Agricola 69:19-25.

Walters Ch, Ballesteros D, Vertucci VA (2010). Structural mechanics of seed deterioration: Standing the test of time. Plant Science 179:565-573.

Weiss D, Ori N (2007). Mechanisms of cross talk between gibberellin and other hormones. Plant Physiol 144:1240-1246.

Xiong L, Lee H, Ishitani, Zhu JK (2002). Regulation of osmotic stress responsive gene expression by LOS6/ABA1 locus in Arabidopsis. Journal of Biological Chemistry 277(10):85888596.

Zhang M, Wang Z, Yuan L, Yin C, Cheng J, Wang L, Huang J and Zhang $\mathrm{H}$ (2012). Osmopriming improves tomato seed vigor under aging and salinity stress. African Journal of Biotechnology 11:6305-6311. 